\title{
KRT13 Gene
}

National Cancer Institute

\section{Source}

National Cancer Institute. KRT13 Gene. NCI Thesaurus. Code C107625.

This gene is involved in epithelial cell structure. 